\title{
Design and Fabrication of a Double Chamber Microbial Fuel Cell for Voltage Generation from Biowaste
}

\section{Anand Parkash*}

Department of Chemical Engineering, Mehran University of Engineering \& Technology, Jamshoro, Pakistan

\begin{abstract}
Electrical energy needs in Pakistan are expected to continue to rise. The use of petroleum as a source of energy still dominates, although oil reserves in Pakistan are increasingly being depleted. Therefore, there is a need to develop alternative source of sustainable energy, such as, Microbial Fuel Cell (MFC). MFC shows another type of renewable energy by changing natural matter into power with the help of microbes. In the current study, an attempt has been made to find the effect of molar concentration of salt bridge on electron transferring potential and to find the efficiency of bioelectricity generation by yeasts such as Hansenula anomala and Saccharomyces cerevisiae. Maximum current of $1.9 \mathrm{mV}$ and $1.4 \mathrm{mV}$ was generated by yeasts Hansenula anomala and Saccharomyces cerevisiae in $1 \mathrm{M}$ potassium chloride salt bridge with duration of $96 \mathrm{hrs}$. This work also demonstrates the feasibility of using yeasts Hansenula anomala and Saccharomyces cerevisiae for current generation, in a mediator less MFC. During the metabolism the fuels like glucose gets oxidized when they pass through the metabolic cycle. The possibility of alternative sources is one particular method of generating power is with the help of microbial fuel cell, which can minimize the usage of fossil fuels. MFCs can produce energy directly from biomass (electricity production) or producing hydrogen from biomass (fuel production). Biological fuel cell converts the chemical energy of carbohydrates such as sugar and alcohol indirectly into electrical energy.
\end{abstract}

Keywords: Salt bridge; Electrical energy; Microbial fuel cell; Saccharomyces cerevisiae

\section{Introduction}

Every year the global energy demand increases. Approximately $86 \%$ of the world energy production comes from fossil fuels. Fossil fuels especially petroleum. Coals are being exhausted, leading to an energy crisis in the near future [1-4]. Furthermore the combustion of the fossil fuels adds $\mathrm{CO}_{2}$ to the atmosphere and causes global warming. Consequently there is a need to develop a new type of energy source as alternative to fossil fuels [5-7]. To overcome this energy requirement mankind has been exploring the possibility of alternative sources of energy and has been trying tapping the energy resources of all origin; solar power, nuclear power, water power, wind power, geothermal power, tidal power, wave and ocean currents etc. One particular method of generating power is with the help of fuel cell, which can minimize the usage of fossil fuels [8,9]. Unlike chemical fuel cell, such as methanol and hydrogen fuel cells, biofuel cells operate under mild reaction conditions, mainly ambient operational temperature and pressure. They also employ neutral electrolyte and use inexpensive catalyst such as copper rods. In Microbial Fuel Cell (MFC) the catalyst is either a microorganism or an enzyme. Biological fuel cell converts the chemical energy of carbohydrates such as sugar and alcohol, indirectly into electrical energy $[10,11]$. As most organic substrate undergoes combustion with the evolution of energy, biocatalyst oxidation of organic substances by oxygen at the two electrode interfaces provides a means for the conversion of chemical energy into electrical energy. MFC may be best described as a bioreactor, where microbes act as biocatalyst in metabolizing the organic substances containing the organic carbon to generate electricity $[12,13]$. Electrons are produce by the oxidation of organic materials in which microbes act as catalyst $[14,15]$. The electrons thus produced are transferred to a terminal accepter such as $\mathrm{O}_{2}$, nitrate and sulphate. These terminal electron accepters are get reduced by these electrons $[16,17]$. A new product is found which can leave the cells when terminal electron acceptors are diffused into the cells. However, there are some microbes specially yeast that can transfer their electrons in the outer space surrounding the cells which are accepted by the awaiting terminal electron acceptors $[18,19]$. These types of microbes are called exogenic and cab be utilized to generate electricity within a MFC. The advantages of MFC are easily available exogenic materials which are used as substrate and microbes which act as biocatalyst [20]. It is a simple system and unlike the hydrogen fuel cells, a MFC does not require extremely synchronized division system. It is more effective than enzymatic fuel cell in harvesting electrons from transport system of microbes [21]. This MFC mainly consists of two chambers, one of the chambers, where, oxidation takes place is call anodic chamber (anode) and the other chamber where reduction takes place is called cathodic chamber (cathode) [12-15]. In the presence of oxygen, microbes oxidize organic compounds to produce $\mathrm{CO}_{2}$ and $\mathrm{H}_{2} \mathrm{O}$, but if the reaction takes place in anaerobic environment then microbes decomposes organic materials to produce $\mathrm{CO}_{2}$, while proton and electrons are produced simultaneously [22-24]. Electrons thus produced are transfer to the cathodic chamber via an external circuit while protons are transferred through salt bridge [23]. These flow of electrons generate voltages [24]. Unique design adjustments utilized these years have given huge yields and opened wild in the multidisciplinary MFC research [24,25]. The aim of this research is to take the inward assents of waste materials, like sewage sludge using double chamber MFC for electricity generation and concentrates on the study including different centralizations of salt in salt extension of an arbiter MFC. This paper focuses on the study involving various concentrations of salt in salt bridge of a mediator MFC.

*Corresponding author: Anand Parkash, Department of Chemical Engineering Mehran University of Engineering \& Technology, Jamshoro, Pakistan, Tel: 0333796-2266; E-mail: parwani_anand@yahoo.com

Received July 24, 2015; Accepted August 05, 2015; Published August 10, 2015

Citation: Parkash A (2015) Design and Fabrication of a Double Chamber Microbia Fuel Cell for Voltage Generation from Biowaste. J Bioprocess Biotech 5: 246 doi:10.4172/2155-9821.1000246

Copyright: @ 2015 Parkash A. This is an open-access article distributed under the terms of the Creative Commons Attribution License, which permits unrestricted use, distribution, and reproduction in any medium, provided the original author and source are credited. 


\section{Materials and Methods}

\section{Strain}

In the present study Hansenula anomala Strain number: 237 and Saccharomyces cerevisiae Strain number: 2918 Procured from MTCC Chandigarh, India was used. The stock culture was maintained separately in slant and stored in refrigerator.

\section{MFC components}

Microbial Fuel Cell majorly constitutes Electrodes, Anodic and Cathodic Chamber and Salt Bridge. The Anodic chamber is an anaerobic chamber, which holds the substrate and the biocatalystMicroorganisms. The cathodic chamber was maintained in aerobic condition. The salt bridge that forms a bridge between cathodic and anodic chamber facilitates the transfer of ions (protons). Graphite electrodes were used as anode and cathode.

\section{MFC set-up construction}

A two chambered fuel cell was constructed. Two plastic containers each with diameter $20 \mathrm{~mm}$ were taken and marked cathode and anode. Two holes of diameter $6 \mathrm{~mm}$ and $1.5 \mathrm{~mm}$ were made on each of the lids for the insertion of the salt bridge and electrodes. In the anode container, 300 $\mathrm{mL}$ of the anodic inoculation was used and in the cathode container 300 $\mathrm{ml}$ Potassium dichromate solution was used and the anodic container lids were closed air tight and sealed with tape (Figure 1).

\section{Salt bridge preparation}

Salt bridge was made with $5 \mathrm{~mm}$ diameter level tube. The salt bridge was prepared using Potassium chloride with 5\% Agar was boiled for 5-10 minutes. The mixture was sucked into the level tube and allowed to solidify. This individual salt bridge was inserted into the corresponding MFC and sealed with tape.

\section{Electrodes used}

Graphite rod from HB Pencil of $10 \mathrm{~cm}$ length was used as electrodes to collect the electrons in both anode and cathode with copper wire connections at the other hole on both the containers and sealed with tape. These electrodes were relatively inexpensive and available easily. The electrodes were pretreated in $100 \%$ ethanol for $30 \mathrm{~min}$. After this the electrodes were washed in $1 \mathrm{M}$ hydrochloric acid followed by $1 \mathrm{M}$ Sodium hydroxide, each for $1 \mathrm{hr}$ to neutralize and to remove possible inorganic contaminants. They were then stored in distilled water before use.

\section{Construction of Hansenula anomala biofuel cell}

Anodic inoculation: $50 \mathrm{~mL}$ of $24 \mathrm{hrs}$. old broth culture of Hansenula anomala along with $200 \mathrm{ml}$ of sterile nutrient broth containing 1\% glucose was prepared and transferred to anodic chamber, anaerobic condition was maintained.

\section{Construction of Saccharomyces cerevisiae biofuel cell}

Anodic inoculation: $50 \mathrm{~mL}$ of $24 \mathrm{hrs}$. old broth culture of Saccharomyces cerevisiae along with $200 \mathrm{ml}$ of sterile nutrient broth containing $1 \%$ glucose was prepared and transferred to anodic chamber, anaerobic condition was maintained.

\section{Result and Discussion}

\section{Efficiency of bioelectricity generation}

The efficiency of bioelectricity generation was tested in between the two strains Hansenula anomala and Saccharomyces cerevisiae. The cell voltage was measured for the mediator less MFC using a multimeter for every twenty four hour. This value was monitored over a period of 15 days was tabulated (Table 1 and Figures 2-8).

The concentration of salt in salt bridge is highly critical in transporting the hydrogen ions. Maximum current of $1.9 \mathrm{mV}$ and $1.4 \mathrm{mV}$ was generated by Hansenula anomala and Saccharomyces cerevisiae in 1 Molar potassium chloride Salt Bridge with duration of $96 \mathrm{hrs}$. The results showed that 1 Molar potassium chloride was suitable for efficient bioelectricity generation were as 2 Molar potassium chloride the maximum bioelectricity generated was $1.2 \mathrm{mV}$ and 1.3 $\mathrm{mV}$ by Hansenula anomala and Saccharomyces cerevisiae. $1.3 \mathrm{mV}$ by both strains in $3 \mathrm{M}$ potassium chloride, varied with duration. Earlier Muralidharan et al. constructed Microbial Fuel Cells (MFCs) represent a new form of renewable energy by converting organic matter into electricity with the help of bacteria already present in waste water. The efficiency of bioelectricity generation was tested in between the two strains Hansenula anomala and Saccharomyces cerevisiae. The results showed that both the strains having the capability to generate bioelectricity. Hansenula anomala more efficiently generated bioelectricity with a short duration confirming that it oxidizes

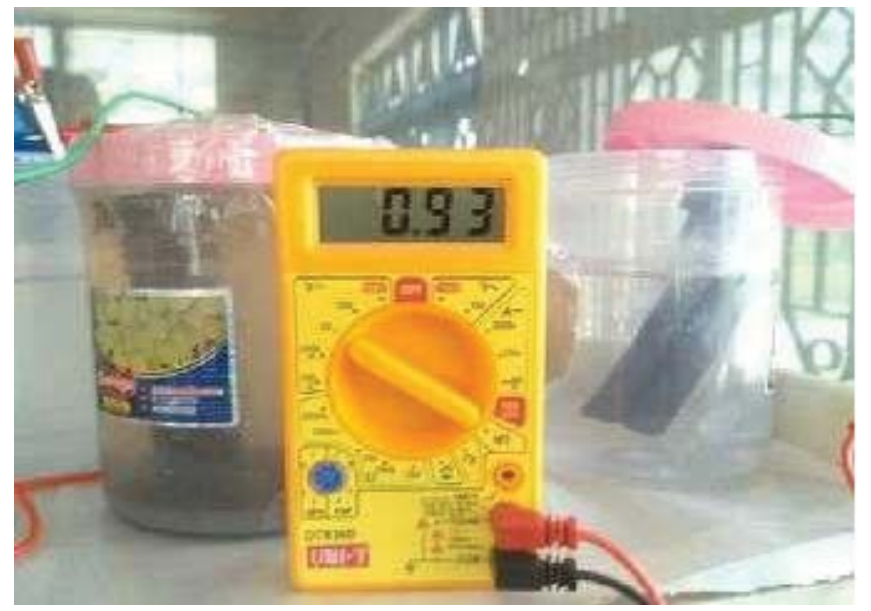

Figure 1: Fabricated MFC

\begin{tabular}{|c|c|c|c|c|c|c|}
\hline \multirow{3}{*}{$\begin{array}{l}\text { Number } \\
\text { of days }\end{array}$} & \multirow{2}{*}{\multicolumn{3}{|c|}{$\begin{array}{c}\text { Electricity generation }(\mathrm{mV}) \text { in } \\
\text { Hansenula anomala } \\
\text { Molar concentration }\end{array}$}} & \multirow{2}{*}{\multicolumn{3}{|c|}{$\begin{array}{c}\text { Electricity generation }(\mathrm{mV}) \text { in } \\
\text { Saccharomyces cerevisiae } \\
\text { Molar concentration }\end{array}$}} \\
\hline & & & & & & \\
\hline & $1 \mathrm{M}$ & $2 \mathrm{M}$ & $3 M$ & $1 \mathrm{M}$ & $2 \mathrm{M}$ & $3 M$ \\
\hline 1 & 0.9 & 0.3 & 0.4 & 0.5 & 0.4 & 0.3 \\
\hline 2 & 1.3 & 0.5 & 0.5 & 0.7 & 0.7 & 0.4 \\
\hline 3 & 1.5 & 1.1 & 1.4 & 1.3 & 1.2 & 0.8 \\
\hline 4 & 1.9 & 1.3 & 1.5 & 1.6 & 1.4 & 1.7 \\
\hline 5 & 1.8 & 1.3 & 1.6 & 1.5 & 1.2 & 1.6 \\
\hline 6 & 1.7 & 1.4 & 1.7 & 1.4 & 1.2 & 1.5 \\
\hline 7 & 1.6 & 1.3 & 1.8 & 1.3 & 1.2 & 1.4 \\
\hline 8 & 1.5 & 1.2 & 1.3 & 1.3 & 1.1 & 1.3 \\
\hline 9 & 1.5 & 1.2 & 1.2 & 1.2 & 1.0 & 1.2 \\
\hline 10 & 1.4 & 1.1 & 1.1 & 1.2 & 0.9 & 1.1 \\
\hline 11 & 1.3 & 0.9 & 1.0 & 1.1 & 0.9 & 0.9 \\
\hline 12 & 1.2 & 0.7 & 0.9 & 1.1 & 0.8 & 0.8 \\
\hline 13 & 1.1 & 0.5 & 0.8 & 1.0 & 0.7 & 0.7 \\
\hline 14 & 0.9 & 0.3 & 0.7 & 0.8 & 0.5 & 0.6 \\
\hline 15 & 0.8 & 0.1 & 0.5 & 0.5 & 0.4 & 0.3 \\
\hline
\end{tabular}

Table 1: Effect of molar concentration on salt bridge. 


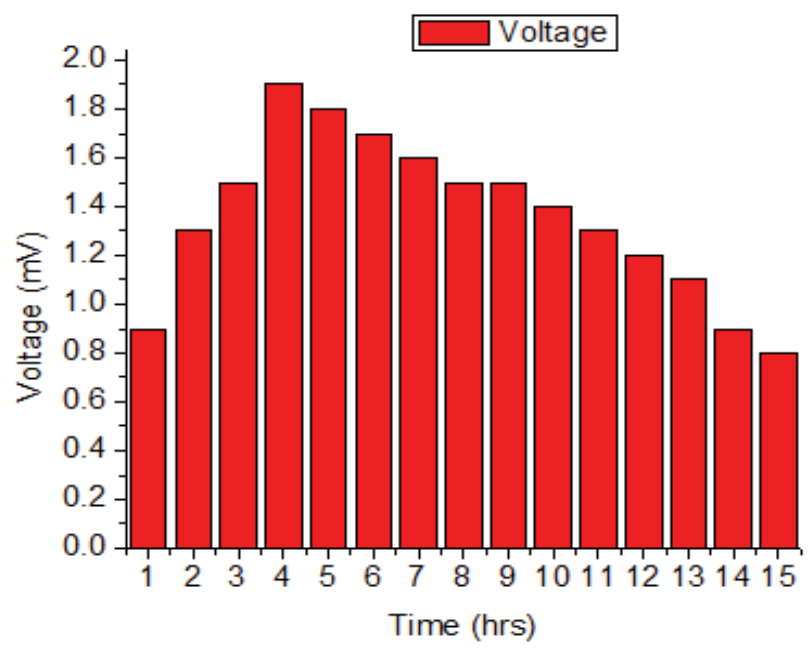

Figure 2: Voltage generated by Hansenula anomala in $1 \mathrm{M} \mathrm{KCl}$ salt bridge at 96 hrs. duration.

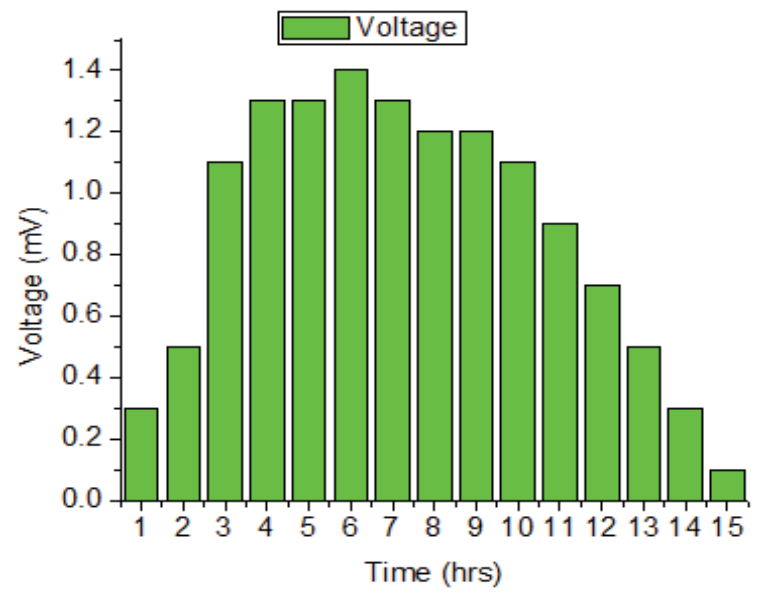

Figure 3: Voltage generated by Hansenula anomala in $2 \mathrm{M} \mathrm{KCl}$ salt bridge at 96 hrs. duration.

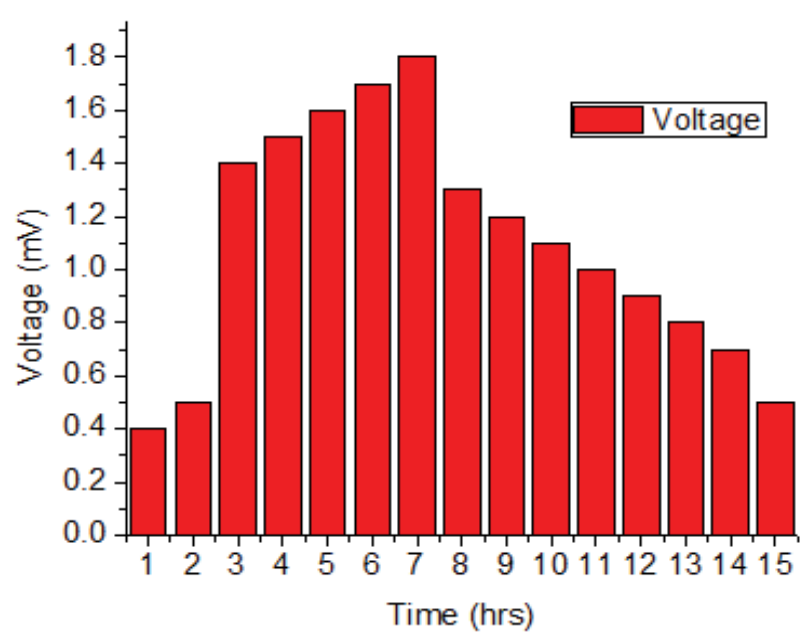

Figure 4: Voltage generated by Hansenula anomala in $3 \mathrm{M} \mathrm{KCl}$ salt bridge at 96 hrs. duration.

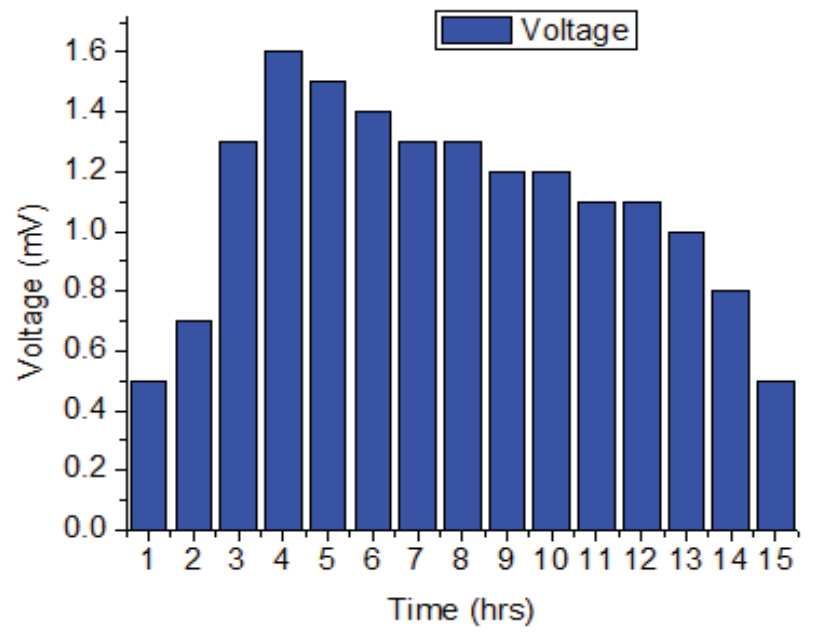

Figure 5: Voltage generated by Saccharomyces cerevisiae in $1 \mathrm{M} \mathrm{KCl}$ salt bridge at $96 \mathrm{hrs}$. duration.

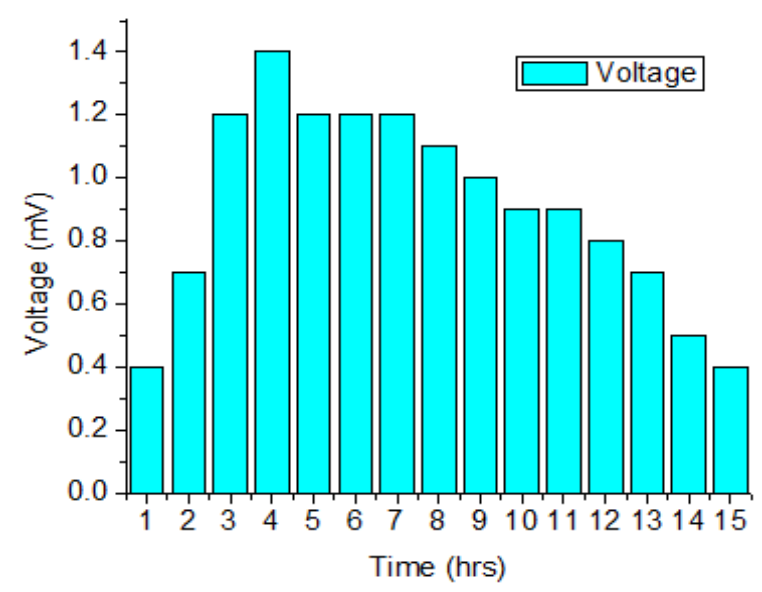

Figure 6: Voltage generated by Saccharomyces cerevisiae in $2 \mathrm{M} \mathrm{KCl}$ salt bridge at $96 \mathrm{hrs}$. duration.

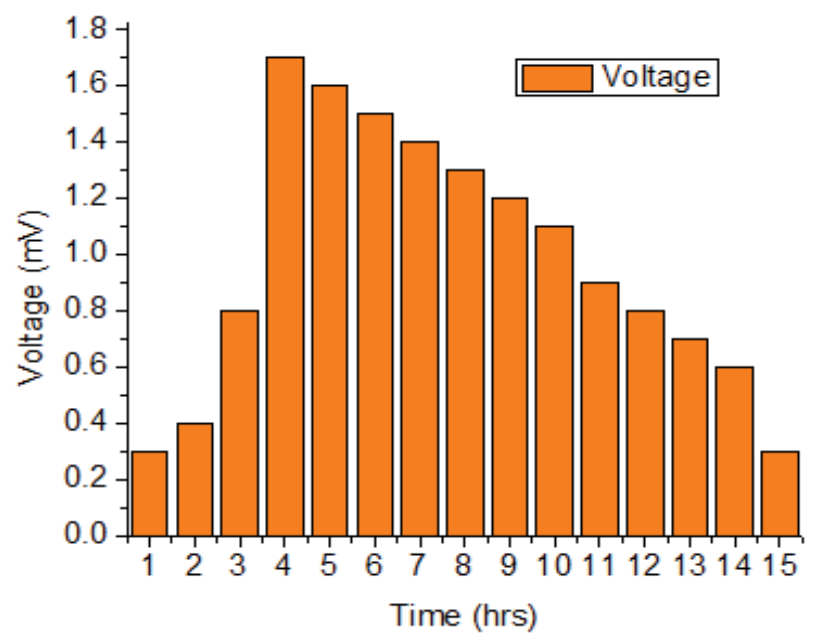

Figure 7: Voltage generated by Saccharomyces cerevisiae in $3 \mathrm{M} \mathrm{KCl}$ salt bridge at $96 \mathrm{hrs}$. duration. 


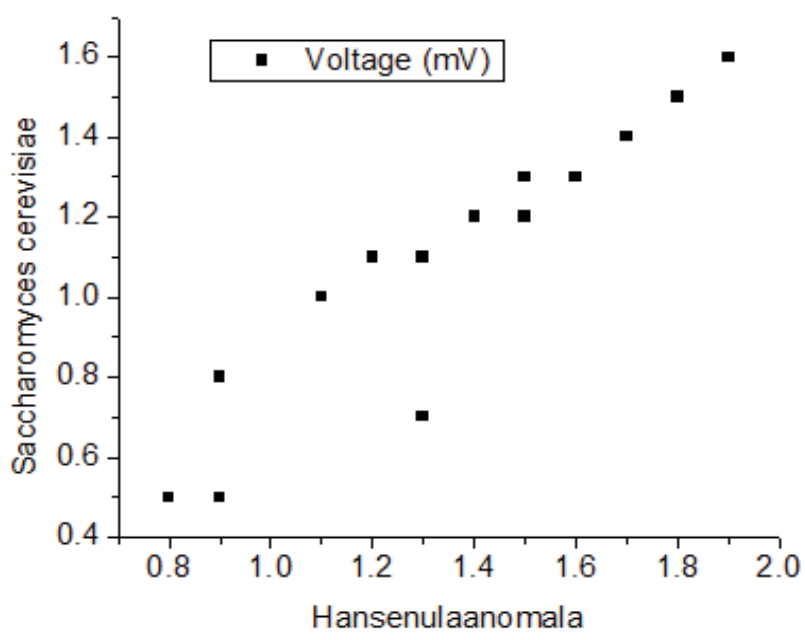

Figure 8: Efficiency of Voltage generation Hansenula anomala vs. Saccharomyces cerevisiae in $1 \mathrm{M}$ Salt Bridge.

glucose rapidly when compared to Saccharomyces cerevisiae. Biofuel cells will become part of the technology mainstream through multiple, incremental breakthrough in materials, components and infrastructures. Only when all the pieces fall into place perhaps 10 years from now, the emergence of a true industrial-sized fuel cell supply chain will be seen. The results obtained were helpful in designing an optimized MFC reduced cost, increased yield are central to successful commercial employment of MFC.

\section{Conclusion}

In the present work, an attempt has been made to find the effect of molar concentration of salt bridge on electron transferring potential and to find the efficiency of bioelectricity generation by yeasts such as Hansenula anomala and Saccharomyces cerevisiae. Maximum current of $1.9 \mathrm{mV}$ and $1.4 \mathrm{mV}$ was generated by yeasts Hansenula anomala and Saccharomyces cerevisiae in 1 Molar potassium chloride salt bridge with duration of $96 \mathrm{hrs}$. This work also demonstrates the feasibility of using yeasts Hansenula anomala and Saccharomyces cerevisiae for current generation, in a mediator less MFC. Power generation even in the absence of mediators the analytical data revealed that the double-chambered Mediator less MFC with salt bridge as proton exchange membrane is more effective for practical applications such as bio-electricity generation and waste-water treatment due to easy scaleup, eco-friendliness, cost effectiveness, reduced operational conditions, accelerated oxygen diffusion and direct electron transfer to anode.

\section{References}

1. Chang IS, Kim BH, Lovitt RW, Bang JS (2001) Effect of CO partial pressure on cell-recycled continuous CO fermentation by Eubacterium limosum KIST612. Process Biochem 37: 411-421.

2. Chang IS, Jang JK, Gil GC, Kim M, Kim HJ, et al. (2004) Continuous determination of biochemical oxygen demand using microbial fuel cell type biosensor. Biosens Bioelectron 19: 607-613.

3. Chang IS, Moon H, Jang JK, Kim BH (2005) Improvement of a microbial fuel cell performance as a BOD sensor using respiratory inhibitors. Biosens Bioelectron 20: 1856-1859.

4. Cheng X, Shi Z, Glass N, Zhang L, Zhang J, et al. (2004) A review of PEM hydrogen fuel cell contamination: Impacts, mechanisms, and mitigation. J Power Sources 165: 739-765.

5. Gong M, Liu X, Trembly J, Johnson C (2007) Sulfur-tolerant anode materials for solid oxide fuel cell application. J Power Sources 168: 289-298.
6. Kim IS, Chae KJ, Choi MJ, Verstraete W (2008) Microbial fuel cells: recent advances, bacterial communities and application beyond electricity generation. Environ Eng Res 13: 51-65.

7. Kim JR, Min B, Logan BE (2005) Evaluation of procedures to acclimate a microbial fuel cell for electricity production. Appl Microbiol Biotechnol 68: 23-30.

8. Lee J, Phung NT, Chang IS, Kim BH, Sung HC (2003) Use of acetate for enrichment of electrochemically active microorganisms and their 16S rDNA analyses. FEMS Microbiol Lett 223: 185-191.

9. Liu H, Cheng S, Logan BE (2005) Production of electricity from acetate or butyrate using a single-chamber microbial fuel cell. Environ Sci Technol 39: 658-662.

10. Pham TH, Jang JK, Chang IS, Kim BH (2008) Improvement of cathode reaction of a mediatorless microbial fuel cell. J Microbiol Biotechnol 14: 324-329.

11. Ragauskas AJ, Williams CK, Davison BH, Britovsek G, Cairney J, et al. (2006) The path forward for biofuels and biomaterials. Science 311: 484-489.

12. Gil GC, Chang IS, Kim BH, Kim M, Jang JK, et al. (2003) Operational parameters affecting the performannce of a mediator-less microbial fuel cell. Biosens Bioelectron 18: 327-334

13. Song C (2008) Fuel processing for low-temperature and high-temperature fue cells: Challenges and opportunities for sustainable development in the $21^{\text {s }}$ century. Catal Today 77: 17-49.

14. Aelterman P, Rabaey K, Pham HT, Boon N, Verstraete W (2006) Continuous electricity generation at high voltages and currents using stacked microbial fue cells. Environ Sci Technol 40: 3388-3394.

15. He Z, Minteer SD, Angenent LT (2005) Electricity generation from artificial wastewater using an upflow microbial fuel cell. Environ Sci Technol 39: 5262 5267.

16. Liu H, Logan BE (2004) Electricity generation using an air-cathode single chamber microbial fuel cell in the presence and absence of a proton exchange membrane. Environ Sci Technol 38: 4040-4046.

17. Rabaey K, Clauwaert P, Aelterman P, Verstraete W (2005) Tubular microbial fuel cells for efficient electricity generation. Environ Sci Technol 39: 8077-8082.

18. Schröder U, Niessen J, Scholz F (2003) A generation of microbial fuel cells with current outputs boosted by more than one order of magnitude. Angew Chem Int Ed Engl 42: 2880-2883.

19. You S, Zhao Q, Zhang J (2006) A microbial fuel cell using permanganate as a cathodic electron acceptor J Power Sources 162: 1409-1415.

20. You S, Zhao Q, Zhang J (2006) A graphite-granule membrane-less tubular aircathode microbial fuel cell for power generation under continuously operational conditions. J Power Sources 173: 172-177.

21. Jiansheng H, Ping Y, Yong G, Zhang K (2011) Electricity generation during wastewater treatment: An approach using an AFB-MFC for alcohol distillery wastewater. Desalination 276: 373-378.

22. Oh ST, Kim JR, Premier GC, Lee TH, Kim C, et al. (2010) Sustainable wastewater treatment: how might microbial fuel cells contribute. Biotechnol Adv 28: 871-881.

23. Du Z, Li H, Gu T (2007) A state of the art review on microbial fuel cells: A promising technology for wastewater treatment and bioenergy. Biotechnol Adv 25: 464-482

24. Zhao F, Harnisch F, Schroder U (2006) Application of pyrolyzed iron (II) phthalocyanine and CoTMPP based oxygen reduction catalysts as cathode materials in microbial fuel cells. Biotechnol Lett 30: 1771-1776.

25. You SJ (2005) Identification of denitrifying bacteria diversity in an activated sludge system by using nitrite reductase genes. Biotechnol Lett 27: 1477-1482. 